\title{
Role of defense enzymes in the induction of host resistance to leaf blight of turmeric (Curcuma longa L.)
}

\author{
K. S. Shilpashree and M. S. Sharada* \\ Department of Studies in Botany, University of Mysore, Manasagangotri, Mysore-570006, Karnataka, India \\ *Corresponding author Email: shilpashreeks6@gmail.com
}

(Submitted on February 15, 2020; Accepted on May 23, 2020)

\begin{abstract}
The present study highlights the role of defense-related enzymes such as phenylalanine ammonia-lyase (PAL), peroxidase (POX) and polyphenol oxidase (PPO) in inducing resistance in turmeric against fungal leaf blight pathogen Alternaria alternata (Fr.) Keissler designated as CL1 which was isolated from the infected leaf of Curcuma longa $\mathrm{L}$. and subsequently identified on the basis of morphological and molecular sequencing studies. The results of our study indicated that defense enzymes activity was maximum at $24 \mathrm{~h}$ for PAL, $12 \mathrm{~h}$ for POX and $48 \mathrm{~h}$ for PPO, respectively upon pathogen inoculation in resistant cultivar. The enzyme activity increased significantly $(P<0.05)$ in resistant genotype upon pathogen inoculation. Indeed, the increase in enzyme activities was not significant in case of susceptible genotypes. It is quite apparent from the study that in host-pathogen interaction, the initial infection process involved conidium germination followed by penetration through stomata in both the genotypes. However, it was considerably slow in Hassan-8 genotype due to its resistant nature. The DNA sequence of this pathogenic Alternaria alternata CL1 has been submitted to NCBI GenBank under the accession number MN307311.

Keywords: Turmeric, leaf blight, phenylalanine ammonia-lyase, peroxidase, polyphenol oxidase,
\end{abstract}

\section{INTRODUCTION}

Turmeric (Curcuma longa L.) is a perennial herbaceous plant belonging to family Zingiberaceae which is well known as the Golden spice or spice of life in the Vedic literature. India is a world's major producer of turmeric which is mostly cultivated in Andhra Pradesh followed by Maharashtra, Tamil Nadu, Orissa, Karnataka and Kerala (Velayudhan et al., 2012). It is one plant which has been in use since times immemorial because of its therapeutic relevance in the treatment of some of the dreaded ailments including cancer, cardiovascular diseases, as hepatoprotectant, and in gastrointestinal disorders, etc.

Turmeric is prone to several diseases like rhizome rot, leaf blight and anthracnose (Kavitha et al., 2012). Among these, leaf blight disease, which is caused by Alternaria alternata (Fr.) Keissler is an important foliar disease usually found in Karnataka in South India damaging this crop to a larger extent by size and weight reduction of the rhizome, thereby afftecting quality, quantity as well as marketability. Normally pathogen infections are the most significant stress stimuli that these plants encounter during their growth. In response to such stress stimuli, certain specific pathogen induced enzymes are produced in the host, which play a major role in the defense mechanism against the pathogens.

The typical symptoms of the disease under study include the formation of bright to pale yellow leaf spots on the upper surface of leaf surrounded by green or yellow halo. The disease cycle is very simple and no teleomorph is reported so far (Aveling et al., 1994). Following infection the symptoms are reported to become apparent after $24 \mathrm{~h}$ which is followed by continued expansion of lesions resulting in the killing of the afftected portion by host selective ACT-toxin (Allen et al., 1983). It has also been documented that for minor infection to occur there is a requirement of leaf wetness by $4-8 \mathrm{~h}$ duration, however, for substantial infection to occur there is a requirement of $10-12 \mathrm{~h}$ of wetness in the leaf (Caihos et al., 1997).

Various events of pathogenesis involving Alternaria like appressoria formation, penetration and conidia germination in diverse hosts have been studied in detail (Aveling et al., 1994; McRoberts and Lennard, 1996). Most of the research in this regard has been undertaken in susceptible hosts. The histopathological studies comparing the events of pathogenesis in resistant and susceptible genotype and in tissues with different ages are very scarce. The study of hostpathogen interaction involving $A$. cassiae and sicklepod (Cassia obtusifolia) using light microscopy and scanning electron microscopy has been undertaken by Van Dyke and Trigiano (1987). The pathogen and host plant interaction induces certain changes in cell metabolism, primarily in enzyme activities.

So far not much information is available on the sporulation, germination of conidia, infection process by A. alternata and the histopathological changes taking place on turmeric leaves as a consequence of infection. So as to study the process of pre-penetration, penetration and infection processes of $A$. alternata on resistant and susceptible genotypes of turmeric using light and scanning electron microscopy analysis and to understand the role of defensive enzymes in the induction of host resistance, the present investigation was undertaken.

\section{MATERIALSAND METHODS}

Collection of plant material: Turmeric samples were collected from Puttunpura, Hangla Malliyaapura, and Basavanpura, Gundulpet Taluk; Hampapura from K.R. Nagar; Bogarahally from Hassan District; Paalya from Kollegal Taluk; Goravanahally from Maddur taluk of Karnataka, India.

Pathogen isolation: The pathogen isolation was done using standard blotter method and by growing on PDA. For this purpose the sterilized Petri plates were furnished with 3 layers of sterile blotter discs so as to absorb moisture content from the infected Curcuma longa leaf material. Typical spots were cut into $1-2 \mathrm{~cm}$ pieces and surface sterilized with $2 \%$ sodium hypochlorite solution for $2 \mathrm{~min}$. Later washed with double distilled water twice to remove sodium hypochlorite and the 
samples were transferred aseptically to the Petri plates. The inoculated plates were incubated for 1 week at $37{ }^{\circ} \mathrm{C}$ with $12 / 12$ hour alternative light and dark periods. After 1 week of incubation, the plates were observed for sporulation and development of the pathogen. The microscopic examination was carried out and culture characters noted.

For isolation of Alternaria alternata the PDA Petri plates were inoculated with leaf samples and subsequently incubated at $28 \pm 2{ }^{\circ} \mathrm{C}$ at an alternative period of $12 / 12$ hour light and dark periods for 1 week. After 1 week, the plates were observed for the growth of the fungal pathogen. The fungal colonies were observed on Petri plates and then subcultured on fresh PDA plates to obtain pure cultures.

Treatment of pathogen with plant: The isolated pathogen was tested for its capability to cause infection on 30 days old turmeric seedlings under the greenhouse environment. The sporangial suspension was used for this purpose. The conidia were harvested from 7 days old fungal pathogen culture and the suspension prepared $\left(1 \times 10^{5}\right.$ conidia $\left./ \mathrm{mL}\right)$ and sprayed on turmeric leaf samples. The whole setup was then covered with plastic covers for $24 \mathrm{~h}$. After 5 days, the inoculated plant samples were observed for disease symptoms. Plants sprayed only with sterile distilled water served as control.

Estimation of PAL activity: The harvested turmeric leafsamples ( $1 \mathrm{~g}$ each) at $0,6,12,24,48$ and $72 \mathrm{~h}$ were homogenized in $1 \mathrm{~mL}$ of ice-cold $25 \mathrm{mM}$ Tris-buffer $(\mathrm{pH} 8.8)$, containing $250 \mu \mathrm{L}$ of $\beta$ - mercaptoethanol. The obtained extract was centrifuged at $10000 \mathrm{rpm}$ for $30 \mathrm{~min}$ at $4{ }^{\circ} \mathrm{C}$ and supernatant was used as an enzyme source. A reaction mixture containing $0.3 \mathrm{~mL}$ of enzyme extract was incubated with 1.2 $\mathrm{mL}$ of $25 \mathrm{mM}$ Tris-HCl buffer ( $\mathrm{pH} 8.8)$ and $1.5 \mathrm{~mL}$ of $10 \mathrm{mM}$ L-phenylalanine in the same buffer for $2 \mathrm{~h}$ at $40{ }^{\circ} \mathrm{C}$. The activity was stopped using $5 \mathrm{~N} \mathrm{HCl}$. PAL activity was determined as the rate of conversion of L-phenylalanine to trans-cinnamic acid at $290 \mathrm{~nm}$. Enzyme activity was expressed as $\mu \mathrm{mol}$ of trans-cinnamic acid/mg protein $/ \mathrm{h}$. Each experiment was repeated in triplicates (Dickerson et al. 1984).

Estimation of POX activity: The harvested turmeric leafsamples ( $1 \mathrm{~g}$ each) at the above mentioned time intervals were homogenized in $1 \mathrm{~mL}$ of $10 \mathrm{mM}$ potassium phosphate buffer (pH 6.9) in a pre-chilled Mortar and Pestle. The homogenate was centrifuged at $12000 \mathrm{rpm}$ for $20 \mathrm{~min}$ at $4^{\circ} \mathrm{C}$ to get the supernatant and used as an enzyme source. POX activity was determined according to the method described by Hammerschmidt et al. (1982) with minor modifications. The reaction mixture of $3 \mathrm{~mL}$ consisted of $0.25 \%(\mathrm{v} / \mathrm{v})$ guaiacol in $10 \mathrm{mM}$ potassium phosphate buffer ( $\mathrm{pH}$ 6.9) containing 10 $\mathrm{mM}$ hydrogen peroxide. $10 \mu \mathrm{L}$ of crude enzyme extract was added to the reaction mixture to initiate the reaction which was recorded spectrophotometrically at $470 \mathrm{~nm}$. The POX activity was expressed as an increase in absorbance at 470 $\mathrm{nm} / \mathrm{mg}$ protein/min. Each experiment was repeated in triplicates.

Estimation of PPO activity: The harvested turmeric leafsamples (1 g each) were macerated in $100 \mathrm{mM}$ potassium phosphate buffer ( $\mathrm{pH}$ 6.5). PPO activity was assayed spectrophotometrically according to the method described by Mayer et al (1965) with slight modifications. The standard reaction mixture consisted of $3 \mathrm{~mL}$ of $10 \mathrm{mM}$ sublimated catechol in $100 \mathrm{mM}$ potassium phosphate buffer $(\mathrm{pH}$ 6.5) and $10 \mu \mathrm{L}$ of enzyme extract. Change in absorbance was recorded at $420 \mathrm{~nm}$ for $1 \mathrm{~min}$. The results are expressed as the change in $420 \mathrm{~nm} / \mathrm{min} / \mathrm{mg}$ protein. Each experiment was repeated in triplicates.

Protein estimation: Estimation of protein content was determined according to the method described by Lowry et al (1951), using BSA (Sigma) as the standard. The reaction mixture consists of $10 \mu \mathrm{L}$ of sample and the volume was made up to $1 \mathrm{~mL}$ using distilled water. To the same solution, $1.5 \mathrm{~mL}$ solution $\mathrm{C}(50 \mathrm{~mL}$ of $0.2 \mathrm{~g} \mathrm{NaOH}, 1 \mathrm{~g} \mathrm{Na} 2 \mathrm{CO} 3,0.01 \mathrm{~g}$ sodium tartarate $+\mathrm{CuSO} 4,0.02 \mathrm{~g}$ in $5 \mathrm{~mL}$ water) was added and mixed well and incubated at room temperature for $10 \mathrm{~min}$. Later 250 $\mu \mathrm{L}$ of Folin's reagent was added to each tube and mixed. The reaction mixture in the test tubes was again incubated at room temperature for $30 \mathrm{~min}$ and optical density (OD) was recorded at $660 \mathrm{~nm}$. The blank solution contains $1.5 \mathrm{~mL}$ solution $\mathrm{C}+250 \mu \mathrm{L}$ Folin's reagent. In another set of tubes containing BSA solution, $1.5 \mathrm{~mL}$ solution $\mathrm{C}+250 \mu \mathrm{L}$ Folin's reagents were added and incubated. The standard curve was drawn against $\mu \mathrm{g}$ of BSA. From the standard curve, the amount of protein in the sample was determined and the protein/gram of sample was calculated.

Preparation of sample and inoculation for light microscopic studies: The conidia were harvested from 7 days old culture of fungal pathogen and the conidial suspension was adjusted $\left(1 \times 10^{5}\right.$ conidia/mL) using a hemocytometer. The surface-sterilized leaf-bits of susceptible and resistant turmeric leaves were dip-inoculated with the conidial suspension $\left(1 \times 10^{5}\right.$ conidia/mL) and incubated for different time intervals viz, 2, 4, 6, 8, 12 and 24 $\mathrm{h}$. The inoculated seedlings were removed from the conidial suspension fixed in acetic alcohol $(1: 3)(\mathrm{v} / \mathrm{v})$ and processed further for histological observations.

Preparation of plant materials for histological observation: The fixed seedlings were partially macerated in $3 \%$ sodium hydroxide for $30 \mathrm{~min}$ at $60^{\circ} \mathrm{C}$ and washed with running water for 30 minutes to remove sodium hydroxide. The washed seedlings were transferred to $0.2 \%(\mathrm{w} / \mathrm{v})$, warm cotton blue and stained for $2 \mathrm{~h}$.

Isolation of fungal genomic DNA: The isolated fungal pathogen designated as CL1 was cultured in PDB medium for 7 days at $28{ }^{\circ} \mathrm{C}$ and mycelium was harvested by vacuum filtration. The chilled mycelia were grinded with pestle and mortar under liquid nitrogen and transferred into a microcentrifuge tube with $1 \mathrm{~mL}$ of $2 \times \mathrm{CTAB}$ extraction buffer and incubated at $65^{\circ} \mathrm{C}$ for $30 \mathrm{~min}$ with gentle swirling. After centrifugation at $10000 \mathrm{rpm}$ for $8 \mathrm{~min}$, the aqueous phase of the mixture containing total DNA was extracted with an equal volume phenol:chloroform:isoamyl alcohol (25:24:1). Residual phenol was removed by the addition of chloroform:isoamyl alcohol (24:1) twice. 2 vol ethanol and 0.1 volume $3 \mathrm{M}$ sodium acetate was added to the aqueous phase of DNA to precipitate and incubated at $-20{ }^{\circ} \mathrm{C}$ over- 
night. DNA pellet was washed with $70 \%$ ethanol and suspended in $15 \mu \mathrm{L}$ of TE buffer. The extracted DNA quality in terms of integrity was detected in agarose gel $(1 \%)$ electrophoresis using ethidium bromide for the visualization at UV light (Kim et al., 2010).

PCR amplification: ITS region of the fungus were amplified by ITS primers, ITS1 5'TCCGTAGGTGAACCTGCGG 3') and ITS4 (5' TCCTCCGCTTATTGATATGC 3') (White et al., 1990). The PCR amplification was carried out in $0.2 \mathrm{~mL}$ PCR tubes, using Master cycler personal (Eppendorf). The PCR reaction mixture $(50 \mu \mathrm{L})$ contained $5 \mu \mathrm{L} 10 \times \mathrm{PCR}$ buffer containing $15 \mathrm{mM} \mathrm{MgCl}_{2}, 5 \mu \mathrm{L} 2 \mathrm{mM}$ each deoxynucleoside triphosphates (dNTPs), $2 \mu \mathrm{L}$ of each primer $(5 \mathrm{pmol} / \mu \mathrm{L}), 4 \mu \mathrm{L}$ template DNA, $2 \mu \mathrm{L}(1 \mathrm{U} / \mathrm{mL})$ Taq polymerase and deionosed water $(30 \mu \mathrm{L})$. Thermal cycling conditions were as follows: initial denaturation $\left(4 \mathrm{~min}\right.$ at $95^{\circ} \mathrm{C}$ ), followed by 30 cycles of denaturation $\left(94^{\circ} \mathrm{C}\right.$ for $\left.50 \mathrm{~s}\right)$, annealing $\left(51^{\circ} \mathrm{C}\right.$ for 1 min), and primer extension $\left(72^{\circ} \mathrm{C}\right.$ for $\left.1 \mathrm{~min}\right)$, followed by final extension for $10 \mathrm{~min}$ at $72{ }^{\circ} \mathrm{C}$. Amplification products were electrophoretically resolved on $1.4 \%(\mathrm{w} / \mathrm{v})$ agarose gel containing ethidium bromide $(0.5 \mu \mathrm{g} / \mathrm{mL})$, using $1 \times \mathrm{TAE}$ buffer at $70 \mathrm{~V}$ (Bhagat et al., 2012).

Taxon sampling and phylogenetic analysis: ITS sequence data was annotated using Geneious 6.1. software and submitted to National Centre for Biotechnology Information (NCBI) GenBank. ITS rDNA sequences with maximum identity to strain CL1 were retrieved from the NCBI database using BLAST search tool. DNA sequences were filtersearched and the closest sequences were selected for the phylogenetic study. The multiple sequence alignments were performed using the Clustal Omega alignment program utilizing the default settings and a dendrogram was generated using MEGA 4.0 with a bootstrap consensus of 1000 replicates.

Tissue preparation for scanning electron microscopy: The infected tissue segments of $10 \mathrm{~mm}$ from $A$. alternata infected and healthy turmeric leaves were collected and fixed in formalin - propionic - proponaol (1:1:8) (FPP) for $1 \mathrm{~h}$. The tissue sections were dehydrated in gradient concentration (50 $\%$ to $90 \%$ ) using isopropyl series later embedded in paraplast followed by softening by $1 \%$ sodium lauryl sulfate for $48 \mathrm{~h}$. The dried tissue sections were mounted on aluminum stubs using double - stick tape which were previously sputtercoated ( $20 \mathrm{~nm}$ gold palladium) and visualized under scanning electron microscope.

\section{RESULTS}

Pathogen isolation: The isolated pathogen from the infected leaf tissue of Curcuma longa (Fig.1A) has been identified as Alternaria alternata CL1 (Fig. 1B) based on the symptoms, morphology, growth pattern, color and characteristics of the colony, surface texture, hyphae and characteristics of the spores (Fig. 1C). Molecular analysis confirmed the identity of the isolated pathogen.

Estimation of PAL activities in turmeric genotypes: Both resistant and susceptible genotypes of turmeric leaf samples showed increase in PAL activity after fungal pathogen inoculation (Fig. 2A). In resistant turmeric leaves, high

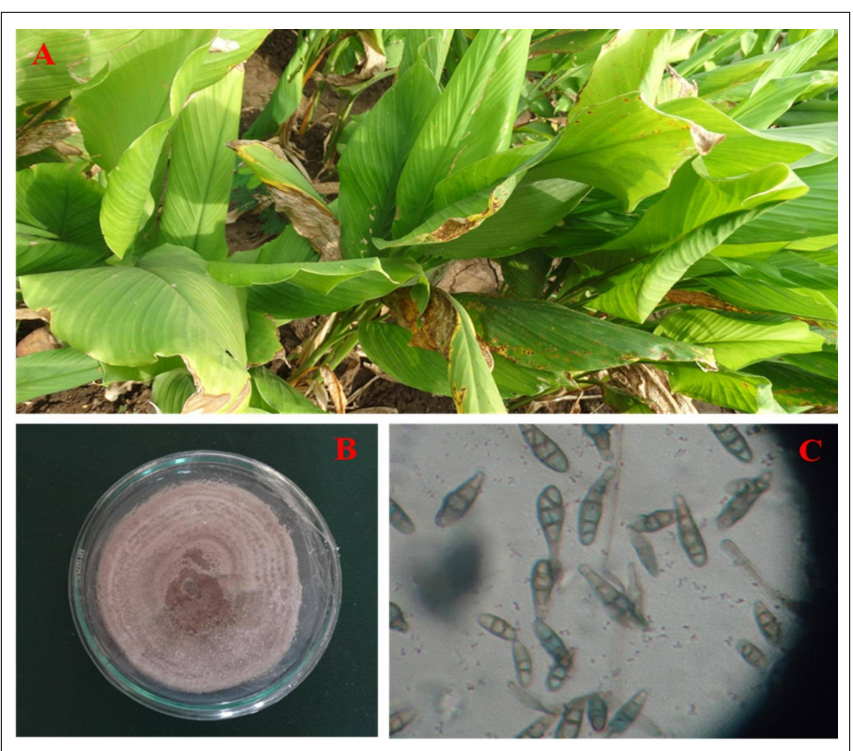

Fig. 1: (A) Curcuma longa L (B) Colony morphology of Alternaria alternata CL1 on PDA (C) Microscopic features of $A$. alternata $\mathrm{Cl} 1$

PAL activity of $159.5 \mathrm{U}$ was recorded in Hassan-8 variety and least activity was recorded in susceptible variety, Hangla-1 (57.3 U).

Estimation of POX enzymes in different turmeric genotypes: Two diverse genotypes, one resistant and other susceptible genotypes of turmeric leaf samples were analyzed for POX with or without pathogen inoculation. Both genotypes showed an increase in the level of enzyme activities after pathogen inoculation (Fig. 2B). High POX activity of $10.23 \mathrm{U}$ was observed in Hassan-8 which was inoculated with fungal pathogen whereas the least activity of POX was found in variety Hangla-1 $(2.73 \mathrm{U})$ after pathogen inoculation showing significant $(\mathrm{p} \leq 0.05)$ difference between their respective control samples.

Spectrophotometric estimation of PPO enzymes in different turmeric genotypes: Both turmeric genotypes showed varied levels of enzymes exhibiting an increase in PPO activitiy after pathogen inoculation (Fig. 2C). The highest PPO activity was observed in variety Hassan-8 (14.41 $\mathrm{OD}$ at $420 \mathrm{~nm} / \mathrm{mg}$ protein $/ \mathrm{min}$ ), showing a 3.6 -fold increase when compared to control (8.43 OD at $420 \mathrm{~nm} / \mathrm{mg}$ protein/min). Less activity level was recorded in susceptible variety Hangla-1 (5.24 OD at $420 \mathrm{~nm} / \mathrm{mg}$ protein $/ \mathrm{min}$ ) turmeric leaf samples upon pathogen inoculation compared to control (1.61 OD at $420 \mathrm{~nm} / \mathrm{mg}$ protein $/ \mathrm{min}$ ).

Light microscopic analysis: Light microscopic details of 24 profusely grown germ tubes of conidia in the infected leaves surface lesions are depicted in Fig. 3. In B-Hallia susceptible genotype penetration of pathogen fungal hyphae into intercellular space was recorded at 24 hpi (Fig. 3). No such penetration was observed in Hassan- 8 genotype at 24 hpi. Some hyphal structures of $A$. alternata were found to spread around the intercellular spaces of the parenchyma tissues via the wounds of the turmeric-leaves. Few germ-tubes were seen 


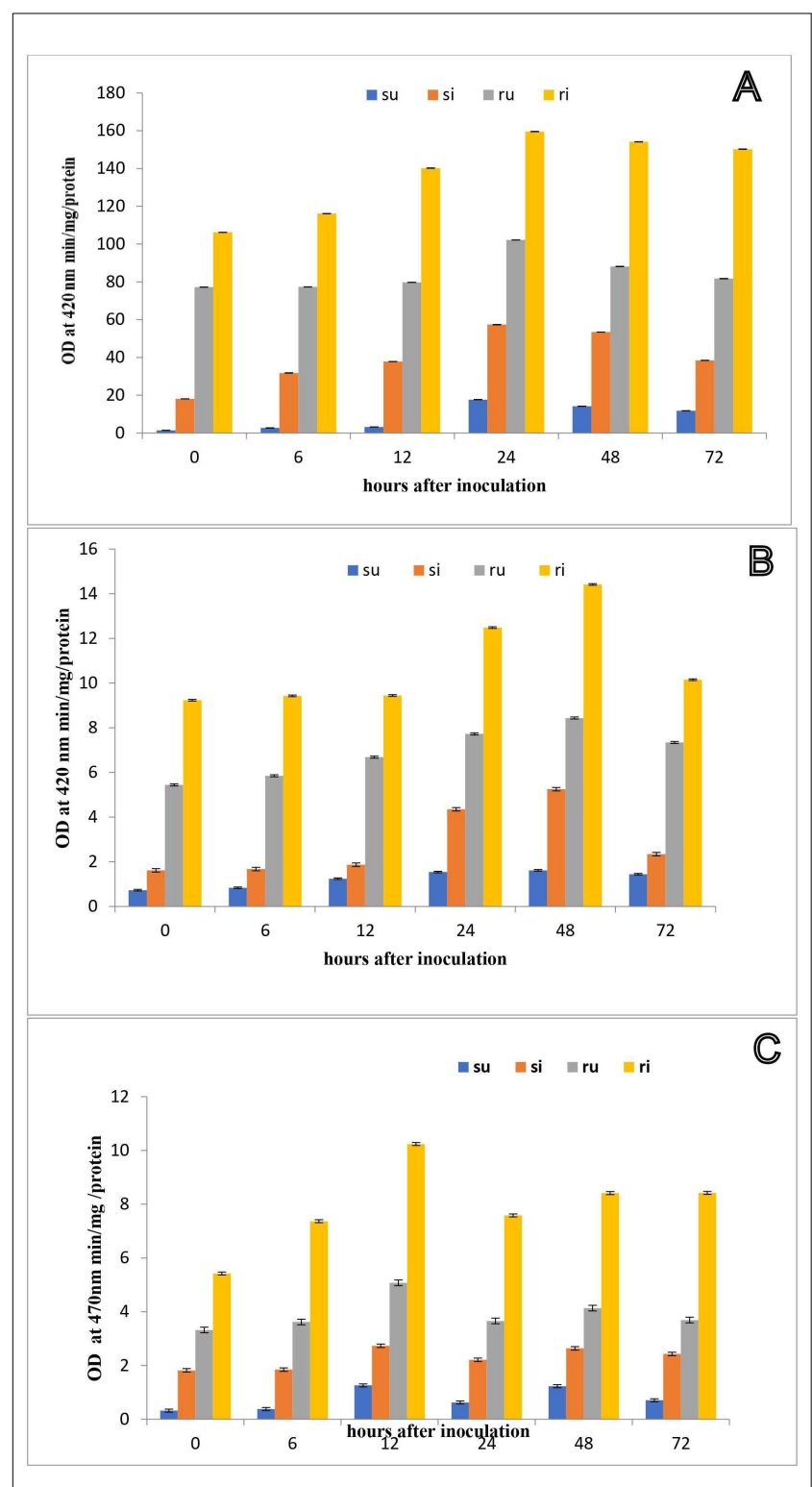

Fig. 2: (A) PAL activity in different turmeric varieties at $24 \mathrm{~h}$ with and without $A$. alternata CL1 inoculation. (B) POX activity in different turmeric varieties at $12 \mathrm{~h}$ with and without A. alternata inoculation. (C) PPO activity in different turmeric varieties at $48 \mathrm{~h}$ with and without $A$. alternata inoculation. The data expressed as the average of three independent experiments with three replicates each.

growing and entering the stoma without forming an appressorium over the stoma. The other germ-tubes though branched and formed no appressoria, exhibited no directional growth towards the stomata. Occasionally branched germ tubes formed a hyphal network on the host tissues and penetrated through the stomata. This study also showed that the hyphae did not penetrate the xylem tissue.

Taxon sampling and phylogenetic affiliation: Strain CL1 was identified using morphological characters and phylogenetic analysis. The amplified ITS region of DNA (Fig. 4A) was sequenced and aligned with similar ITS DNA
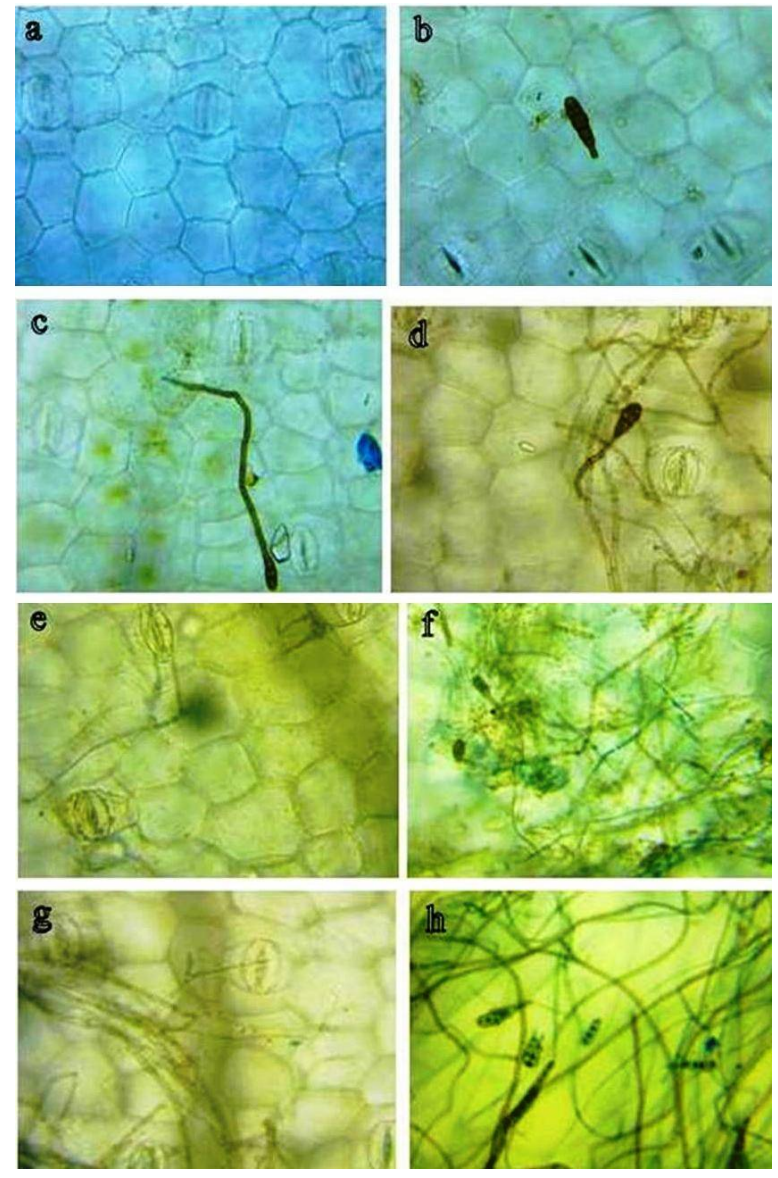

Fig. 3: Alternaria alternata $\mathrm{Cl1}$ infecting the leaf surface near stomata/penetration thorough stomata ( 0 to 72 hours)

of the different isolates retrieved from NCBI GenBank using CLUSTALW (Thompson et al., 1994). Corresponding neighbor-joining (NJ) analysis showed clearly that strain CL1 fell into the group of Alternaria alternata with strong support (Fig. 4B). The DNA sequence of this pathogenic A. alternata strain CL1 is submitted to

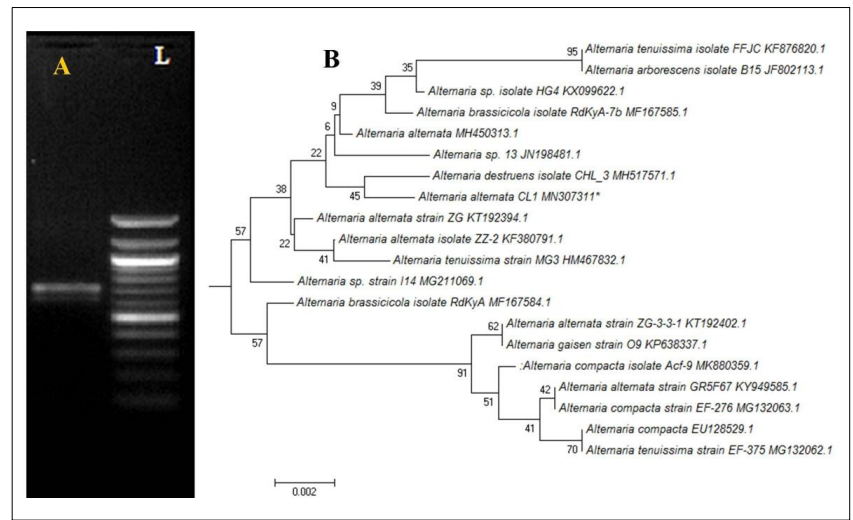

Fig. 4: (A) PCR amplification of Alternaria alternata CL1 DNA by internal transcribed spacer (ITS1 and ITS4) universal primers (B) Phylogenetic tree derived from neighborjoining analysis showing the evolutionary relationship of A. alternata CL1 with its closest BLAST hits 


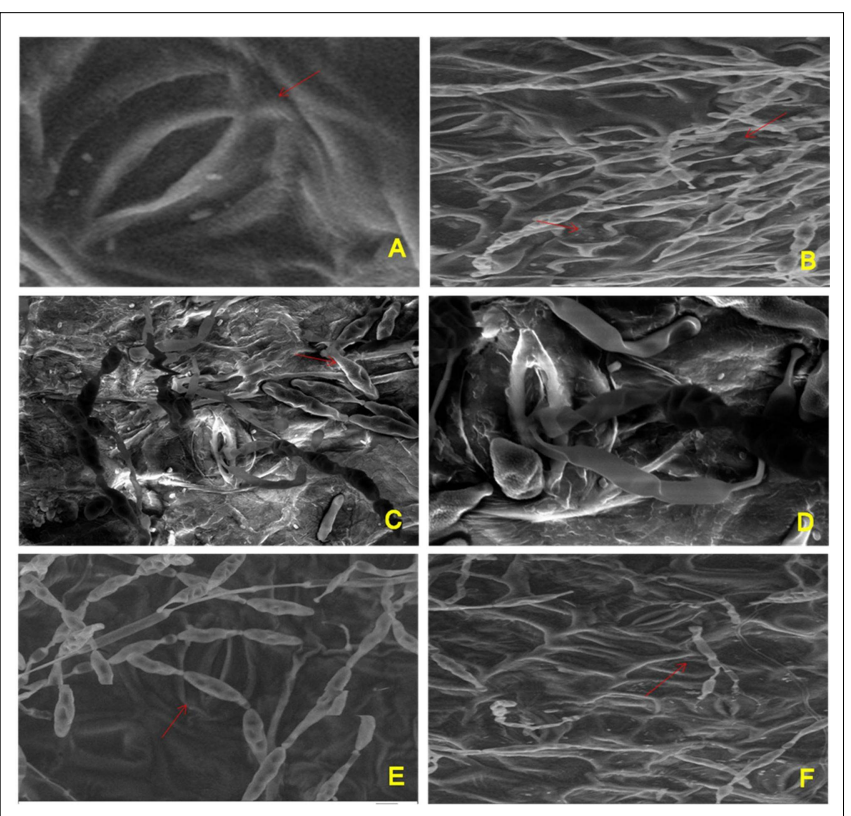

Fig. 5: (A) Control plants showing no infection of Alternaria alternata CL1 in stomatal aperture. (B) Susceptible genotype B-Halli showing the infection in leaves. (C) Conidial infection in susceptible genotype B-Halli showing the infection in stomatal aperture. (D) Stomatal aperture invaded by infection hyphae emanating from conidial spores of A. alternata. (E) Hassan-8: genotype which is not showing infections by A. alternata after $24 \mathrm{~h}$. (F) Hassan-8: genotype which is not showing infections of A. alternata after $24 \mathrm{~h}$

NCBI GenBank under the accession number MN307311.

\section{DISCUSSION}

During the study of host-pathogen interaction between turmeric and Alternaria alternata strain CL1 all the eight turmeric varieties used exhibitted clear variation in the degree of their resistance to the pathogen. PAL is an enzyme of the phenylpropanoid pathway that is induced during plantpathogen interaction. Chen et al. (2000) showed the production of high level of PAL in cucumber root inoculated with Pythium aphanidermatum. Geetha et al. (2005) suggested the involvement of PAL in the resistance mechanisms of pearl millet to Sclerospora graminicola. An early increase in PAL activity in rice plant have been reported upon infection with Pyricularia oryzae blast pathogen (Wang et al., 2004). Indeed plants are reported to have abundant enzymatic resources like PAL, POX, PPO, peroxidases,etc. that contain iron as heme and are involved in the scavenging of $\mathrm{H}_{2} \mathrm{O}_{2}$ by the oxidation of phenols and its generation, through the oxidation of NADH. The induction of POX appears to be an early event in the defense of host against pathogen during plant-microbe interaction (Shivalingaiah and Umesha, 2016).

Rotem (1994) documented that spores of all Alternaria sp. germinate in a remarkably less time and formed many germtubes which entered via the stoma with no appressorium formation. Similar observations were made by Allen et al. (1983) while investigating $A$. helianthi interaction with sunflower. Results of the present study also exhibited both direct and indirect penetrations with or without formation of appressoria, suggesting that appressoria formation is not necessary for the infection. Similar observations were made by Van Dyke and Trigiano (1987) while investigating pathogenesis of A. alternata. This pathogen has been reported to enter their specific host via the stomata and by direct penetration with or without appressoria formation. Von Ramm (1962) also documented that A. longipes penetrated tobacco leaf without appressoria formation. Mims et al. (1997) reported that conidia of A. cassiae germinated in 2-3 hpi producing multiple germ-tubes which grew across leaves surface. In this study, germ tube is reported to enter via stoma with no appressorium formation. The results of the present study exhibited both direct and indirect penetration without the formation of appressoria suggesting that appressoria formation is not necessary for initiating the infection process.

Lesions formed in leaf tissues of resistant genotypes and in young leaves exhibit slow expansion rate in comparison to expansion in susceptible genotypes or old leaves (Dita et al., 2006). This slow colonization in resistant genotypes and young leaves might be primarily due to some of the defense related reactions initiated from within such hosts during hostpathogen interaction. Dehpour et al. (2007) reported the formation of secondary hyphae from primary hyphae which anastomoses in the intercellular space and also grow intercellularly within the epidermis. There is a report of $A$. brassicicola and $A$. brassicae entering the leaves tissue of Brassica oleracea and B. juncea, by direct and stomatal penetration. Similar observations have been made in case of infection of castor leaves by $A$. ricini and onion leaves by $A$. porri (Suheri and Price, 2000; Babu et al., 2009).

During present study, an attempt has also been made to study the resistance and susceptibility of diverse turmeric genotypes against $A$. alternata by considering PAL, POX and PPO as biochemical markers. From amongst the different turmeric genotypes evaluated a potent source of resistance was documented in only Hangla-1 genotype, which exhibited minimum disease incidence. As for other genotypes are concerned none of them were free from leaf blight disease symptoms after the pathogen inoculation and in all of them susceptibility was high. During the interaction, we documented the direct involvement of PAL, POX and PPO in turmeric inoculated with A. alternata. Spectrophotometric investigation for POX and PPO enzymes in resistant and susceptible turmeric leaves samples without pathogen inoculation revealed fewer activities in comparison to the inoculated turmeric leaves sample, suggesting a possible role of these enzymes during pathogen infections and hostresistance. Substantially high activity of PAL, POX and PPO was documented in resistant turmeric leaves sample in comparison to susceptible turmeric leaves sample, thereby clearly suggesting that PAL, POX and PPO have played a significant role in the development of host resistance. The present findings are in conformity with the earlier research work by Chittoor et al. (1997) where the role of POX in resistant interaction between rice and Xanthomonas oryzae pv. oryzae causing bacterial blight disease has been emphasized. 
In a related study Mohammadi and Kazemi (2002) reported significant increase in POX specific activity in both resistant and susceptible wheat genotypes upon inoculation with Fusarium graminearum conidia. Increase in peroxidase activity was considered as an indicator for resistance of beans to chocolate spot disease by Nawar and Kuti (2003). The PPO activity has been reported to significantly increase in resistant and susceptible genotypes of wheat upon inoculation with F. graminearum conidia (Mohammadi and Kazemi, 2002). Similar results have been recorded in plant-pathogenic fungal interaction between cabbage and F. oxysporum, bean and Rhizoctonia, sunflower and Sclerotinia sclerotiorum, onion and Botrytis, soybean and Phytophthora megasperma. Pretreatments of Chick pea with rhizobium has been reported to increase peroxidase, total phenolics and polyphenyl oxidase levels in the host (Arfaoui et al., 2007).

In conformity with the earlier reports the present study also revealed the role of increased PPO levels in the development of resistance in turmeric to leaf blight pathogen. Presently maximun PPO activity at $24 \mathrm{hpi}$ was documented in pathogen inoculated turmeric leaves sample, in comparison to control suggesting that PPO might play an important role to trigger host resistance. Upon inoculation of resistant turmeric leaf samples, elevated levels of POX and PPO was documented which seems to have a role in the inhibition of the growth of pathogen by suppressing attempted invasion thus imparting resistance against leaf blight of turmeric.

\section{CONCLUSION}

The present investigation involving the study of the infection process of Alternaria alternata on termeric has been undertaken for the first time. It has thrown light on the details of pre-penetration, penetration and colonization events in the development of disease syndrome during infection of $A$. alternata on termeric plant, which is a member of family Zingiberaceae. Based upon the investigations undertaken it can be concluded that PAL, POX and PPO can be used as a biochemical marker to indicate the resistance or susceptibility nature of turmeric against $A$. alternata leaf blight disease.

\section{ACKNOWLEDGEMENTS}

We are grateful to the University Grants Commission (UGC) for providing financial assistance in the form of Rajiv Gandhi National Fellowship for SC/ST candidates to the first author. We also express our gratitude to the Department of Studies in Botany, University of Mysore, India for providing instrumentation facilities.

\section{REFERENCES}

Allen, S.J., Brown J.F. and Kochman, J.K. 1983. The infection process, sporulation and survival of Alternaria helianthi on sunflower. Ann. Appl. Biol. 413-419.

Arfaoui, A., El Hadrami, A., Mabrouk, Y., Sifi, B., Boudabous, A., El Hadrami, I., and Chérif, M. 2007. Treatment of chickpea with Rhizobium isolates enhances the expression of phenylpropanoid defense-related genes in response to infection by Fusarium oxysporum f. sp. ciceris. Plant Physiol.

\section{Biochem. 45: 470-479.}

Aveling, T.A.S., Snyman H.G. and Rijkenberg, F.H.J. 1994. Morphology of infection of onion leaves by Alternaria porri. Canadian J. Bot. 72:1164-70.

Babu, A.M., Philip, T., Kumar, V. and Kariappa, B.K. 2009. Germination, penetration and sporulation of Alternaria ricini (Yoshii) Hansf. On castor leaf. Arch. Phytopathol. Plant Prot. 42 (10): 915-921.

Bhagat, J., Kaur, A., Sharma, M., Saxena, A.K. and Chadha, B.S. 2012. Molecular and functional characterization of endophytic fungi from traditional medicinal plants. World J. Microbiol. Biotechnol. 28: 963-971.

Caihos, Y., Erkilic, A. and Timmer, L.W. 1997. First report of Alternaria brown spot of Minneola tangelo in Turkey. Canadian Journal of Plant Pathology 9: 230-235.

Chen, C., Belanger, R.R., Benhamou, N., and Paulitz, T.C. 2000. Defense enzymes induced in cucumber roots by treatment with plant growth-promoting rhizobacteria (PGPR) and Pythium aphanidermatum. Physiol. Mol. Plant. Pathol. 56: 13-23.

Chittoor, J.M., Leach, J. E., and White, F.F. 1997. Differential induction of a peroxidase gene family during infection of rice by Xanthomonas oryzae pv. oryzae. Mol. Plant-Microbe Inter. 10: 861-871.

Dehpour, A.A., Alavi S.V. and Majad, A. 2007. Light and scanning electron microscopy studies on the penetration and infection processes of Alternaria alternata causing brown spot on Minneola tangelo in the West Mazandaran-Iran. World Applied. Sci. J. 2: 68-72.

Dickerson, D.P., Pascholati, S.F., Hagerman, A.E., Butler, L.G., and Nicholson, R.L. 1984. Phenylalanine ammonia-lyase and hydroxycinnamate: CoA ligase in maize mesocotyls inoculated with Helminthosporium maydis or Helminthosporium carbonum. Physiol. Plant Pathol. 25: 111-123.

Dita, M.A., Brommonschenkel, S. H., Matzuoka, K., and Mizubuti, E. 2006. Components of resistance to early blight in four potato cultivars: effect of leaf position. J. Phytopathol. 153: 1-6

Geetha, N.P., Amruthesh, K.N., Sharathchandra, R.G., and Shetty, H.S. 2005. Resistance to downy mildew in pearl millet is associated with increased phenylalanine ammonia lyase activity. Functional Plant. Biol. 32: 267-275.

Hammerschmidt, R., Nuckles, E.M., and Kuć, J. 1982. Association of enhanced peroxidase activity with induced systemic resistance of cucumber to Colletotrichum lagenarium. Physiol Plant. Pathol. 20: $73-82$.

Kavitha, K., Nakkeran, S. and Chandrashekar, G. 2012. Rhizobacterial mediated induction of defense 
enzymes to enhance the resistance of turmeric (Curcuma longa L.) to Pythium aphanidermatum causing rhizome rot. Arch. Documented Plant Prot. 45: 199-219.

Kim, J.S., Seo, S.G., Jun, B.K., Kim, J.W. and Kim, S.H. 2010. Simple and reliable DNA extraction method for the dark pigmented fungus, Cercospora sojina. J. Plant Pathol. 6: 289-292.

Lowry, O.H., Rosebrough, N.J., Farr, A.L., and Randall, R.J. 1951. Protein measurement with the Folin phenol reagent. J. Biol. Chem. 193: 265-275

Mayer, A.M., Harel, E., and Ben-Shaul, R. 1965. Assay of catechol oxidase - a critical comparison of methods. Phytochemistry 5: 783-789

McRoberts, N. and Lennard, J.H. 1996. Pathogen behaviour and plant cell reactions in interactions between Alternaria species and leaves of host and nonhost plants. Plant Pathol. 45: 742-752.

Mims, C.W., Rogers, M.A. and Van-Dyke, C.G. 1997. Ultrastructure of conidia and conidium germination in the plant pathogenic fungus Alternaria cassiae. Canadian J. Bot. 75: 252-260.

Mohammadi, M., and Kazemi, H. 2002. Changes in peroxidase and polyphenol oxidase activities in susceptible and resistant wheat heads inoculated with Fusarium graminearum and induced resistance. PlantSci. 162:491-498.

Nawar, H.F., and Kuti, J.O. 2003. Wyerone acid phytoalexin synthesis and peroxidase activity as markers for resistance of broad beans to chocolate spot disease. $J$ Phytopathol.151: 564-570.

Rotem, J. 1994. 'The genus Alternaria'. The American Phytopathological Society: St Paul, Minnesota, USA

Shivalingaiah and Umesha, S. 2016. Study of involvement of peroxidase and polyphenol oxidase in imparting resistance to bacterial blight disease in Oryza sativa varieties. European Journal of Biotechnology and Bioscience 4(7): 05-10

Suheri, H. and Price, T.V. 2000. Infection of onion leaves by Alternaria porri and Stemphylium vesicarium and disease development in controlled environments. Plant Pathol. 49: 375-382.

Thompson, J.D., Higgins, D.G. and Gibson, T.J. 1994. CLUSTALW: improving the sensitivity of progressive multiple sequence alignment through sequence weighting, position-specific gap penalties and weight matrix choice. Nucleic. Acids Res. 11: 4673-4680.

Van Dyke, C.G. and Trigiano, R.N. 1987. Light and scanning electron microscopy of the interaction of the biocontrol fungus Alternaria cassiae with sicklepod (Cassia obtusifolia). Canadian J. Plant Pathol. 9: 230-235.

Velayudhan, K. C., Dikshit, N., and Nizar, M. A. 2012. Ethnobotany of turmeric (Curcuma longa L.). Indian Journal of Traditional Knowledge 11(4):607614.

Von Ramm, C. 1962. Histological studies of infection by Alternaria longipes on tobacco. Phytopathologische Zeitschrift 45: 391-398.

Wang, L., An, C., Qian, W., Liu, T., Li, J., and Chen, Z. 2004. Detection of the putative cis-region involved in the induction by a Pyricularia oryzae elicitor of the promoter of a gene encoding phenylalanine ammonia-lyase in rice. Plant Cell Rep. 22: 513-518.

White, T.J., Bruns, T.D., Lee, S.B. and Taylor, J.W. 1990. Amplification and Direct Sequencing of Fungal Ribosomal RNA Genes for Phylogenetics. In: PCR Protocols: A Guide to Methods and Applications. (Eds.: Innis, M.A., Gelfand, D.H., Sninsky, J.J. and White, T.J.) Academic Press, New York, 315-322. 